Article

\title{
Sustainability Culture of Polish Universities in Professionalization of Management
}

\author{
Łukasz Sułkowski ${ }^{1}$, Katarzyna Kolasińska-Morawska ${ }^{2}$, Robert Seliga ${ }^{1}$ D, Piotr Buła ${ }^{2}$ and Paweł Morawski ${ }^{3, *}$ \\ 1 Department of Electronic Economy and Logistics, University of Social Sciences, 90-113 Lodz, Poland; \\ lsulkowski@san.edu.pl (Ł.S.); rseliga@san.edu.pl (R.S.) \\ 2 Department of International Management, Management Institute, Cracow University of Economics, \\ 31-510 Cracow, Poland; kolasink@uek.krakow.pl (K.K.-M.); bulap@uek.krakow.pl (P.B.) \\ 3 Department of Management, Lodz University of Technology, 90-361 Lodz, Poland \\ * Correspondence: pawel.morawski.1@p.lodz.pl
}

Citation: Sułkowski, Ł.

Kolasińska-Morawska, K.; Seliga, R.; Buła, P.; Morawski, P. Sustainability Culture of Polish Universities in Professionalization of Management. Sustainability 2021, 13, 13894 https://doi.org/10.3390/ su132413894

Academic Editor: Sandro Serpa

Received: 23 September 2021

Accepted: 9 December 2021

Published: 15 December 2021

Publisher's Note: MDPI stays neutral with regard to jurisdictional claims in published maps and institutional affiliations.

Copyright: (c) 2021 by the authors. Licensee MDPI, Basel, Switzerland. This article is an open access article distributed under the terms and conditions of the Creative Commons Attribution (CC BY) license (https:// creativecommons.org/licenses/by/ $4.0 /)$.

\begin{abstract}
The process of management professionalization is progressing in many universities in the world. It results from the growing importance of technology, globalization, social and economic transformations, including the requirement of competitive operation in market conditions. This process is based on the principles of social responsibility for the quality of services provided with transparency as well as respect for the idea of sustainable development. The subject of the considerations in the article is the impact of sustainable development on the culture of the quality of professionalization of management in universities operating in Poland. The exploratory inspiration came from the authors' own experiences and secondary sources, including books, articles and reports. The research methods used were participant observation and critical analysis of the content of the collected materials. The obtained results made it possible to design and conduct a descriptive and explanatory nomothetic study based on survey with direct questionnaire. The collected material became the basis for implementation of the idea of sustainable development and its impact on the quality culture of professionalization of university management in the future. The suggestions proposed by the authors may be used by university managers to define a development roadmap in the field of professionalization of teaching and organizational processes management based on the concept of sustainable development.
\end{abstract}

Keywords: sustainability culture; higher education; professionalization of management

\section{Introduction}

The concept of sustainable development requires a balanced approach in social, economic and environmental areas [1-4]. Especially policy and educational culture supports the process of mutual understanding for diversity and creating a better world for the future in the trend of sustainable development [5]. The role of sustainable education can be expressed as "learn to know", "learn to act", "learn to live together", "learn to be" and "learn to transform yourself and society" and "learn to live sustainably" [6,7]. In this spirit, education institutions and especially universities are treated as those organizations that should not only create knowledge, but above all create "environment-human-economy balance" solutions based on the ideas of diversity.

Both in practice and in the literature on the university management professionalization, some trends can be observed when it comes to the change of widely understood management in the higher education sector. Changes in the area of higher education are dictated by economic, social or political trends, e.g., globalization, internalization or social economy. At present, the Polish higher education sector is a perfect example of that. The state authorities in charge of higher education have introduced regulations entitled "Act 2.0", which has resulted in a number of changes in higher education. To a large extent, the 
new regulations have led to a transformation in the academic order. In Poland, one can observe massification of higher education, increased competition or partial commercialization of the sector. New legal regulations impose even greater responsibility on universities to take action. Universities ought to act in a transparent manner. This policy is consistent with global trends, assuming the autonomy of universities in the ways of managing their assets and in creating study programs in which universities are required to take responsibility for the quality of the provided services [8]. In the Polish system of higher education, mechanisms aimed at controlling the quality of education have been strengthened through the evaluation of educational programs, research on the scientific development of scientific and teaching staff, evaluation of conducted classes or examination of the career development of graduates.

An important point of the changes in the Polish higher education system is the promotion of the idea of education quality assessment by external institutions among universities. In this way, Polish higher education institutions (HEIs) have a chance to create curricula consistent with international trends and based on common criteria. According to Normand, international institutions, assessing the quality of education at universities, are increasingly becoming regulators. At the same time, they create a coherent quality assessment for all universities, thus ensuring their transparency [9]. The literature on the subject devotes significant attention to the issues of methodology of university quality assessment [10-12], which largely depends on the region in which a given university is assessed. This usually depends on the culture of the country the university comes from. On the other hand, a certain universality of educational quality assessment programs is emphasized, which makes it possible to evaluate universities according to transparent rules and criteria [13-15]. This approach is consistent with the principles of the concept of sustainable development, which refers to issues in the area of socio-economic policies with an impact on other areas, including education, which has and will have a significant impact on the future of societies.

Along with the growing awareness of quality assessment at universities, the number of internal units at universities, whose aim is to control and ensure proper quality of education, has also increased. These units are, in a way, a binder connecting universities with external accreditation bodies. There has been a change in the course of academic culture at universities towards internal control [16]. Such a situation has also been observed over the last decade in Polish HEIs. In the literature on the subject, there are many views on internal quality control at universities [8,17-22]. A common feature of all contemporary views on the issue of internal quality control in HEIs should be its specific responsibility towards the HEI stakeholders and the society itself in international and not only local terms. Such an approach is supported by the fact that universities participating in the processes of international evaluation of education become the guarantor of the quality of their diplomas which can be used all over the world. It is also important to adjust internal units and procedures of quality control at universities to international standards and requirements [23]. While a balanced approach is often and readily included in legal acts and executive documents of universities, it is then difficult to implement specific solutions and monitor progress. Finally, it is extremely important to have it implemented because of the social responsibility of the university as educational units.

In the era of globalization, an important area of universities' activity is their social relation, which should manifest itself in their social responsibility [24,25]. Universities should build this responsibility through transparency and clarity of their management processes. They should be transparent, and the information about procedures and results of control should be open and available to the society. This is a rather complicated issue, considering some kind of limitations occurring at universities, e.g., cultural limitations, resulting from the country of the university origin, or legal constraints. Moreover, institutions examining the quality of universities should act in a transparent way and treat all the universities participating in the assessment process equally. This is only possible if uniform quality assessment procedures and criteria are established. Gaston, on the other hand, points out 
that excessive formalization of qualitative assessment and, consequently, accountability of the university, may contribute to the reduction of its autonomy [26].

In this context, professionalization in university management, based on the idea of sustainable development, reflecting the balance between the systemic approach and academic autonomy resulting from respect for diversity is important. The aim of the article is to discuss the impact of the idea of diversified and sustainable development on the culture of professionalization of management in universities operating in Poland.

The defined research objective was translated into a research problem with the following content: definition and evaluation of the hitherto favorable circumstances and adversities in the implementation and application of solutions for the professionalization of management based on the concept of sustainable development in the structures of the University.

This educational sector is particularly important because it prepares future generations of economic, political, technological and social leaders who will be responsible for introducing the concept of sustainable development into societies' DNA. Ergo universities themselves should be marked by the spirit of sustainable development to "teach sustainable existence". This means that the way they are managed should be sustainable. An exemplification adequate to the requirements of the situation seems to be the concept of professionalization of management based on the sustainable development path.

To determine whether the indicated development direction is expected by the academic community and possible to be achieved, the authors decided to verify the following hypothesis: the idea of sustainable development implemented in the process of university management professionalization influences the creation of a diversified quality culture. Here the following questions arise:

- How to create such sustainable universities?

- Are the universities subject to transformation and already transforming in accordance with the idea of sustainable development?

- Do the employees perceive these changes?

- What decisions concerning the structural and resource components of the universities have already been made?

- What areas of relations with the environment are currently taken care of by the universities?

In order to obtain answers to such questions, the authors had to refer to their own experiences in contacts with scientific and didactic institutions and organizations, analyze the aggregate knowledge in published materials such as books, articles and reports, and obtain information from university employees as members of the academic community. The research methods used in this respect were, respectively, participant observation, qualitative desk research analysis and a questionnaire study on the professionalization of university management.

Maintaining the academic ethos related to social trust in a turbulently changing reality with financial, social and organizational challenges poses an adaptation necessity for higher education. Understanding the approach and operation of Polish universities in the field of professionalization of university management in accordance with the directives of sustainable development is important, according to the authors, for at least two reasonsfirstly because of the authority assigned to universities as guides shaping the minds of future generations and secondly because of the organizational functionality in the socioeconomic structures of countries.

The analysis of the collected material allowed us to determine the theoretical and practical implications of the application of the idea of sustainable development in university management processes, with exemplification in the form of creating possible differentiated formulas of quality culture in universities on the example of Poland.

\section{Sustainability Culture of University}

The notions of "sustainability" and "sustainable development" are increasingly emerging in the science and practice of management in contemporary society, starting with 
business, through international development, and ending up with education and politics $[27,28]$. Both terms are complex in nature, but "sustainable development" can be characterized as a response to the awareness of dynamic economic growth and industrialization which contribute to the degradation of the environment and, consequently, to the dramatic consequences of ecological and social changes. The literature on the subject shows a great diversity regarding the conceptualization and implementation of sustainable development in various academic disciplines [29-32].

In the context of sustainable development, it is worth mentioning the United Nations (UN) initiative, Sustainable Development Solutions Network (SDSN). It was set up in 2012 under the auspices of the UN Secretary General. SDSN mobilizes global scientific and technological expertise to promote practical solutions for sustainable development, including the implementation of the sustainable development goals and the Paris Climate Agreement. SDSN works closely with United Nations agencies, multilateral financing institutions, the private sector, and civil society. SDSN's mission is to promote integrated approaches to implement the sustainable development goals and the Paris Agreement on Climate Change, through education, research, policy analysis, and global cooperation. One of the goals of sustainable development is education quality to ensure inclusive and equitable quality education and promote lifelong learning opportunities for all. According to latest sustainable development report (2021) Poland ranks 15th out of 165 countries with education quality indicator on track and some challenges remain.

The first attempt to define the role of education in contributing to a more sustainable society at the global level was made in the Stockholm Declaration of 1972. In 1990, the first declaration (the Talloires Declaration) was created on the role of higher education in response to the ever-growing global environmental problems. Since then, work on sustainable development in HEIs has continued, both as a mission of universities in shaping society and as a response to the growing importance of sustainable development [33-35].

E. Hoover and M. Harder believe that the role of universities in shaping future members of society and potential leaders is significant. HEIs carry out these tasks by introducing innovations, conducting scientific research and shaping knowledge that contributes to the perception of a world where there can be no lack of sustainable development. It should be stated that not only activities undertaken by universities are crucial, but also the way they are conducted is important $[33,36]$. Changes in the educational quality processes, decision making and organizational structure are able to be carried out only when accompanied by a simultaneous creation of a sustainable quality culture. This is a huge challenge for the higher education sector on a global scale, requiring overcoming internal resistance on the part of academic teachers, legal and organizational barriers, as well as the interests of numerous stakeholders who often have diversified views on the possibility of making changes in the traditional academic order shaped over the years.

A quality culture can be defined in different ways. There is no single definition that clearly characterizes it. J.A. Woods defines a quality culture by combining it with a systemic approach, characterizing six fundamental values that constitute a pro-effective quality culture: (1) focus on processes; (2) learning is crucial; (3) all stakeholders work together towards the same goal; (4) there is open access to all information regarding intraorganizational processes; (5) there is open and transparent communication; (6) there are partner relationships within the organizational structure. Some definitions refer to quality management, while others define it in relation to the activity. In this approach, a quality culture of HEIs is a derivative of academic culture. Over twenty years of experience in managing institutions of the higher education sector in Poland prove that the implementation of a formalized education quality control system does not directly affect the provision of high-quality education. Therefore, the key issue seems to be the engagement of stakeholders in the process of improving quality culture in the higher education sector. Through the increasing participation of internal and external stakeholders, its development is very important and brings results. Therefore, the quality culture in HEIs can be a kind of synthesis of academic culture and business methods of quality management [22]. 
According to the definition of the European University Association, a quality culture is an organizational culture whose main objective is to continuously improve quality. It distinguishes two essential elements of quality culture: the first one has a structural and managerial nature, related to the quality improvement process, whereas the second one concerns cultural and psychological aspects referring to common expectations, beliefs and values in the area of quality improvement. HEIs should manage in such a way that both of these elements support the others in synergy, thus contributing to the systematic development of the higher education sector. The concepts of quality management and quality assurance had emerged earlier than the concept of sustainable quality culture. The latter responds to the emerging concerns of the academic community who are skeptical about the introduction of changes to the existing procedures and tools typical for quality management which do not necessarily have a positive impact on the management process of HEIs [37].

HEIs should strive to create a sustainable quality culture that is achievable through a long-term development that takes into account quality assurance processes, academic ethos and mutual trust of all stakeholders engaged in this process. A sustainable quality culture can be achieved through regular evaluation and control, while balancing excessive bureaucracy. One of the barriers may be fixed financial expenditure and investment in human resources, which constitutes significant costs for universities. On the other hand, the benefits of this should be treated as a long-term investment resulting in increasing a competitive position in relation to other universities and ensuring a high quality of educational offer. The key mechanisms considered to be strategic in the context of creating a quality culture include widespread knowledge sharing, promotion of processes that foster ownership distribution and sharing. Additionally, it is necessary to involve all employees of the university, reduce barriers of change and introduce appropriate supporting mechanisms-all these elements together should contribute to the development of a quality culture of higher education [37-39].

The literature review shows that the features indicating a university with integrated sustainable development include, among others [40-44], the following:

- integrating the concept of sustainable development into teaching and research;

- promotional actions regarding the concept of sustainable development;

- leadership and vision, with an emphasis on sustainable development;

- engagement in social activities that contribute to environmental sustainability.

Universities have a high environmental impact through energy consumption and waste generation. An increasing number of universities are joining the group that has improved environmental management through their activities. Unfortunately, a full integration of sustainable development into the creation of a quality culture is progressing much slower than the "greening" of campuses along with the emergence of a "third wave of sustainability" in the learning-focused higher education sector [45]. The number of universities reporting on sustainability as well as the level of sustainability reports is still far less advanced than that of corporations [46,47].

\section{Professionalization of the University}

In an attempt to understand the expansion of concepts, methods and organizational techniques in universities, we should begin by defining the term "management professionalization". In the dictionary understanding, professionalization is "the process of separating new professions or specialties in a given field, the transformation of some interests, activities into a profession or the acquisition of skills necessary for the profession" [48]. In the literature on the subject, there are a number of terms related to the term professionalization, but only a few connect this term with the area of university management. The nomenclature of management is dominated by two levels of analysis of professionalization [49]. The first one concerns the organization itself, which is professionalizing itself through an efficient allocation of its own resources, and thus gradually becomes more and more effective in achieving its goals. The second perspective focuses on the person 
in the organization who can act professionally and become a professional. The necessary condition for the professionalization of human resources is the increase of competences, including knowledge, skills and attitudes, allowing for permanent, effective action in the organization. Therefore, management professionalization may mean the acquisition and use by the organization and its managers of competences enabling effective management of the organization. Professionalization presupposes organizational sustainability and continuity and strengthens management improvement processes; it is reflected at different levels of the organizational system and therefore concerns both strategies, as well as organizational structures and cultures. Responsibility, reliability, striving to achieve the assumed goals are the characteristics of people, but they are also cultural norms, which can be part of the organizational identity [50].

In the area of organization management, we can see the development of methods and techniques that strengthen the professionalization of management, which in the functionalist-system paradigm is seen as a stage in the organization's pursuit of progress [51]. According to B. Fanning, the process of professionalization is complex and long lasting; however, in the area of human resources management, one can observe a long-term trend, strengthening this process [52]. In many organizations at the strategic level, human capital development plans have been created and implemented, and they have been operationalized in the form of quality systems, procedures, operational plans and schedules [53]. Many researchers emphasize that professionalization is a process that takes into account not only organizational systems and resources but also complex interactions with the dynamic environment of the entity [54].

Professionalization of university management is taking place in many countries and is part of the transformation of the higher education sector. The development of concepts for the management of public and nonpublic universities and the strengthening and improvement of managerial professions in the higher education sector are manifestations of the professionalization of university management in the USA, Great Britain, many EU countries and other parts of the world. Concepts of new public management have disseminated methods of management adopted from business in the public sector, including education [55]. The concept of new public management aims to identify good practices in the field of university management [56]. It should be noted, however, that in a certain part it contradicts the logic of traditional, academic thinking [57]. Nonpublic universities are to a large extent based on business sectors, the best example of which in recent decades may be the expansion of private for-profit universities. Modifications that have occurred in the management of universities can be found in the administrative structures of universities, legal regulations of university functioning, in the missions and strategies of universities and in the values of universities, looking through the prism of changing the "academic ethos". It should be noted that these transformations deeply interfere with the current view on the way universities are managed and their autonomy. The changes in the area of university management are a result of the transformations that have taken place in the university environment, and in particular in the society where there have been changes in the hierarchy of values and norms, standards, customs and widely understood life priorities.

The professionalization of management of public universities is carried out according to the stakeholder model, while nonpublic universities operate more often under the shareholders model, which should, however, take into account the noncommercial nature of the scientific and didactic mission. The literature indicates the need to perceive the professionalization of university management as a kind of dialogue and compromise between stakeholders [58]. S. Collini notes that the professionalization of universities creates an opportunity for them to open up to society in order to meet its needs [59].

The change brought about by the professionalization of university management has been reflected in new practices in relation to various professional groups operating in universities: scientists, didactics and university administration. Traditional administration is developing thanks to professional groups of academic managers, including, for example, chancellors, presidents and rectors (president, rector, provost) registrars, chief information 
officers, presidents and board members of trustees. The gradual increase in management professionalization observed in the Polish higher education sector [60] is caused by several factors, including increased reporting requirements, development of methods of university classification, diversification of universities, growing competition and strengthening of internationalization.

\section{Sustainability Culture Relations between Professionalization of HEI and Sustainability of HEI}

The article attempts to indicate the relationship between sustainability and the concept of professionalization of management in higher education in terms of a culture of quality. This specificity manifests itself in at least a few areas, such as academic culture, methods and techniques of university management, university strategies, degree of cultural diversity of students in the university.

It can be noted that in recent years, universities are increasingly introducing initiatives related to sustainable development. The literature presents different approaches to the implications of university approaches to the subject of sustainable development $[33,47,61]$. The initiatives taken by universities to implement sustainable development are manifested, among other things, in the concentration of universities in the implementation of individual university programs such as student exchanges, the implementation of evaluation of these initiatives and the promotion of education related to the idea of sustainable development $[62,63]$. Lozano et al. [34] as an important barrier to the implementation of sustainable development in universities indicate lack of awareness of the idea of sustainable development and a treating sustainable development as kind of threat to the stable and well-structured academic community. According to the research, the human factor in universities has a significant impact on the process of adaptation of the idea of sustainable development in higher education institutions [64].

The literature also indicates the ambiguity and complexity of the concept of sustainable development itself as a blockade or slowing down the implementation of the idea of sustainable development. According to P. Sylvestre [65], this can lead to a lack of common understanding and willingness to implement, a lack of policy to promote the idea of sustainable development, an overly broad curriculum as a consequence of which it is not possible to add an additional subject in sustainable development, a lack of funding for sustainable development programs for universities [34].

It seems that the basis for the implementation and construction of the concept of sustainable development in modern higher education institutions could be the document Transforming our world: the Agenda 2030 for Sustainable Development, which was adopted at the 70th session of the UN General Assembly in 2015. It is a global and universal document that can be implemented in all countries regardless of the level of economic growth. The Agenda 2030 includes 17 goals for sustainable development. Objective 4 is addressed to the education direction: "Provide quality education for all and promote lifelong learning". This objective should be implemented through a number of specific objectives, including ensuring access to quality education for all genders, nationalities and ages, ensuring access to primary and secondary education for all.

To sum up, it can be concluded that the proper addressees of Agenda 2030 point 4 are universities. They are gaining more and more importance in the implementation of the above-mentioned postulates due to the continuous increase in the number of people entering higher education-the gross enrollment rate in 2019 was 38.85\%. Among the reasons for the increase in this rate are change in the policy of countries encouraging women and minorities to enroll, increase in the wealth of society [66]. An important role in increasing access to higher education was played by private universities, which created conditions and places to study [67-69].

The progress in the implementation of the concept of sustainable development at universities can be dated back to 1990; this year, the representatives of the universities signed Talloires Declaration; it was to promote the key activities that were to serve the development of the concept of sustainable development at universities. In 1992, the Uni- 
versity Leaders for a Sustainable Future (ULSF) was founded. Various organizations were later established, including the Global Higher Education for Sustainability Partnership (established 2000), the Association for the Advancement of Sustainability in Higher Education (established 2005), and the Higher Education Sustainability Initiative (established 2012) [70].

Such a direction of change in the higher education sector is confirmed by the of professionalization occurring in universities. Universities are significantly strengthening their relationship on sustainability issues. This can be seen in numerous examples of reflecting the idea of sustainable development in the strategies and missions of universities, establishing cooperation between partner universities, drawing the attention of universities to environmental aspects (modernization of campuses, construction of green areas), cooperation with government institutions for a sustainable future [71].

An important aspect of the professionalization of the management of universities in the area of sustainable development is to take action in the field of didactics. More and more universities are replacing their infrastructure (e.g., lighting and heating) with the environmentally friendly one and also introducing programs of environmental education, conducting research for the benefit of the environment [72,73]. International funds supporting such initiatives have been and still are an important factor in the development of didactics towards sustainable development $[74,75]$. The support for teaching towards sustainable development is also provided by e-learning and Learning Management System (LMS) programs. The literature points out many benefits and dangers of using modern technologies in the educational process [76].

Implementation of sustainable development in universities requires changes in the area of university organizational structures. Many universities have created specialist, dedicated units specializing in sustainable development. They take care of the realization and implementation of the strategy of sustainable development in the activities of the units, according to the strategy adopted by the universities. In the literature, there are studies on organizational changes in universities and their impact on the directions of sustainable development [61,77].

The directions of sustainable development in universities in the context of the professionalization of management of these units are also seen in the economic development of the university, the mission and strategy of the university, participation in work and in the third mission of the universities (creating mutual relations between the university and its environment). It can be noted that the adjustment of the process of managing universities in the area of sustainable development is characterized by a high degree of diversity. This diversity is influenced by many factors such as the area of university functioning, university status: state/private, development strategy adopted by the university, etc.

One of the fastest growing areas of sustainable development at universities is student exchange. Student exchange between universities enables universities to make a significant contribution to the progress of the concept of sustainable development [78] as, e.g., ERASMUS exchange students contribute to sustainable marketing of the university. Achieving sustainable development goals in the area of quality education, gender quality and reduced inequalities is supported by student exchange because students from less developed countries have access to the best universities. In recent years, there has been a growing discussion about the new role of higher education institutions in the area of sustainable development.

Higher education institutions play and will play an increasingly important role in implementing the concept of sustainable development. Looking at the degree of professionalization of university management in the areas of sustainable development, it is possible to indicate a number of activities that universities can still undertake in order to improve this process. However, at this point, it is also possible to refer to the academic ethos, which can play an important role in the process of impression of sustainable development. It is the duty of universities to educate not only students but also academic teachers who will promote the idea of sustainable development in the future and take care of its implemen- 
tation. According to Salihu there is a strong need to create global educators from the university environment [79]. Their role would be to propose and communicate the idea of sustainable development.

\section{Materials and Methods}

Primary research (descriptive-explanatory) was carried out as part of the project: "Dialog" - the project- "Organizational improvement of universities of the future UNIFUT.PL" (Decision No. 0146/DLG/2017/10) at the turn of 2018 and 2019 in Poland. The subject of the measurement was to gather information about the readiness of the university employees to implement the concept of management professionalization based on the concept of sustainable development. The research method used was survey with direct questionnaire. The measuring tool was a questionnaire consisting of twelve sections of closed questions, including eight based on the scaling of attitudes according to a Likert scale.

Due to the type of information received, these were quantitative and qualitative studies. The identification of the factors and their analysis allowed us to create a statistical picture of the readiness of the university employees to implement the concept of management professionalization based on the concept of sustainable development. Taking into account the focus on the recognition of opinions and attitudes, as well as the scope of perception and interpretation of the rationale of reorganization in the approach to management of the universities, the research can be described as qualitative research.

The empirical material was obtained from primary sources who were employees working directly or indirectly and were involved in the implementation of Act 2.0 (The Law on Higher Education and Science) at universities operating in Poland. Due to the scope of the measurement, the research was fragmentary (a group of representatives of a part of the university was sampled), deterministically characteristic for the surveyed community (Figure 1). The selection for the sample was two-stage.

$$
\mathrm{n}_{\min }=\mathrm{NP}(\alpha 2 \cdot \mathrm{f}(1-\mathrm{f})) / \mathrm{NP} \cdot \mathrm{e} 2+\alpha 2 \cdot \mathrm{f}(1-\mathrm{f})
$$

where

$\mathrm{n}_{\text {min }}$-indicates the minimum sample size

$\mathrm{N}$-the size of the studied population

$\alpha$-confidence level for the results

$\mathrm{f}$-fraction size

e-assumed maximum error

\begin{tabular}{|c|}
\hline Population I type: Universities operating in Poland in the academic year 2018/2019 \\
\hline $\mathrm{n} 1=399$ population of the studied population \\
\hline \\
\hline Sample number of universities operating in Poland in the academic year 2018/2019 \\
\hline $\mathrm{n} 1=38$ sample units (including: 12 public and 26 nonpublic universities) \\
\hline Population II type: Employees of universities operating in Poland in the academic year 2018/2019 \\
\hline $\mathrm{n} 2=99,879$ population size \\
\hline \\
Sample number of employees of universities operating in Poland in the academic year 2018/2019 \\
n2 $=454$ sample units \\
finally: 38 universities $\times 12$ units each \\
nij = 456
\end{tabular}

Figure 1. Sampling scheme. 
In order to maintain the representativeness of the sample examined in the first stage, out of 399 universities operating in Poland in 2018/2019, which constitute the finite population of the surveyed collective units, the layered selection method with proportional allocation with systematic sampling was selected (taking into account the following criteria: public/nonpublic university and the number of employees in public/nonpublic universities) with a 0.9 fraction for public units and 0.1 for nonpublic units, a random error of $6 \%$ and a 0.9 sample size of $\mathrm{n} 1=38$.

Consequently, in the second stage, individual units were examined in the selected collective units, i.e., 38 universities. Using the method of selecting typical units in each of the indicated universities, requests for participation in the study were sent to people who in the last year actively participated in the university management process, performing managerial and administrative functions in various positions (rectors, vice-rectors, heads of scientific units, heads of administrative units). The minimum number of subjects was set at 454 with a fraction of 0.3 for managers and 0.7 for others, a random error of $5 \%$ and a confidence level of 0.99 .

Due to the size of the university's population sample, $\mathrm{n} 1=38$, it was assumed that at each university, at least 12 people would be asked to participate in the study ( $\mathrm{Z}$ index expressing the ratio of the minimum number of the university's sample to the minimum number of university employees), which translated into tested sample of 456 people in total.

$\mathrm{Z}=\mathrm{n} 2 / \mathrm{n} 1$

$\mathrm{Z}=454 / 38$

$Z=11,947 \approx 12$ units

The study was conducted on the basis of the direct questionnaire technique with the use of a measurement tool in the form of a standardized questionnaire, which was filled in by the participants of the study, i.e., people holding managerial and administrative functions in various positions at universities (rectors, vice-rectors, heads of scientific units, heads of administrative units). The study group was dominated by men (59\% of respondents) compared to women (41\% of respondents). The overwhelming group of respondents ( $85 \%$ ) are people between 30 and 60 years of age. Most of the participants $(75 \%)$ held the PhD, DSc and professor titles. More than half of the employees $(55 \%)$ have more than 10 years of work experience, every fifth person (19\%) is in a managerial position and over half $(68 \%)$ are employed in private universities.

$$
\chi^{2}=\sum_{i=1}^{r} \frac{\left(n_{i}-n p_{i}\right)^{2}}{n p_{i}}
$$

where

$\mathrm{p}_{\mathrm{i}}$-means the probability that the feature $X$ takes a value belonging to the $\mathrm{i}$-th class interval $n \mathrm{p}_{\mathrm{i}}$ - denotes the number of units that should be in the i-th interval, assuming that the feature has a distribution consistent with the hypothesis.

In turn, the statistic has the distribution $\chi^{2} \mathrm{o} k=(\mathrm{r}-1)$, where

$k$-means the number of degrees of freedom

$\mathrm{r}$-is the number of class intervals

$x^{2}$-is the empirical value of the statistic obtained from the study

The form of a critical set

$$
p \chi^{2}>\chi^{2} \alpha=\alpha
$$

where $\chi^{2} \alpha$ is the critical value from the distribution tables $\chi^{2}$ for $k=r-1$ degrees of freedom and $p=\alpha$.

The composition of the surveyed sample reflected the surveyed population. The comparative analysis of the population and the sample was performed using the concordance test based on the $\chi^{2}$ statistics. Due to the test procedure, the null hypothesis (H0) was adopted in the first step, saying that the distributions of selected variables (type of univer- 
sity, gender and academic degree) were not consistent with the distributions characterizing the general populations of universities and employees of higher education in Poland, and the alternative hypothesis (H1) about the existence of such compliance.

The result of the analysis is the statement that it was not possible to confirm the null hypothesis (H0) about the lack of conformity of the distributions. Thus, the alternative hypothesis (H1) is true, i.e., the studied samples are consistent with the general community (Table 1). However, due to the nonrandom selection of individual units for the sample, it is difficult to assess the representativeness of the samples in a statistical sense.

Table 1. Sample representativeness-Statistical concordance test $\chi^{2}$.

\begin{tabular}{cccccc}
\hline Parameters & Number & Number & $\begin{array}{c}\text { Value } \chi^{2} \\
\text { Real }\end{array}$ & $\begin{array}{c}\text { Value } \chi^{2} \alpha \\
\text { Theoretical }\end{array}$ & $\begin{array}{c}\text { Test Realization } \\
\chi^{2}<\chi^{2} \alpha\end{array}$ \\
\hline $\begin{array}{c}\text { university status } \\
\text { public } \\
\text { private }\end{array}$ & 12 & 132 & & & \\
& 26 & 267 & 0.039 & 6.635 & concordance \\
female & 186 & 45,698 & Gender & & concordance \\
male & 270 & 54,181 & 4.527 & 6.635 & \\
prof. & 48 & 11,114 & & & \\
dsc. & 102 & 19,907 & & & \\
phD & 194 & 48,939 & 2.566 & 6.635 & concordance \\
master & 112 & 19,919 & & & \\
\hline
\end{tabular}

\section{Results}

The research has been carried out on a representative sample of employees of universities operating in Poland in 2018/2019 and has made it possible to analyze the material in the field of acceptance of the academic community for the concept of sustainable development and the application of solutions in the field of professionalization of management based on the concept of sustainable development. On the basis of the collected material, the perception of the concept of sustainable development in the stream of education for the future was analyzed.

The next step was to analyze the indications regarding the impact of sustainable development on the way of thinking and acting of the university, broken down into public and private universities, taking into account the similarity between them. The last component of the analysis was the analysis of the representation of the idea of sustainable development for the professionalization of activities in university management, broken down into public and private universities, taking into account the similarity between them.

The results presented below constitute only a selected fragment of the analysis and correspond to the nature of the issues discussed in the publication.

The vast majority of the respondents (Figure 2) identify the idea of "Sustainable Development of the University" with supporting the intellectual development of society (30.5\% definitely yes and 52.9\% rather yes) and responsible education and upbringing of generations (29.2\% definitely yes and $49.8 \%$ rather yes). According to the respondent's education for the needs of the labor market (49.8\% definitely not and 3.9\% rather not) and treating employees and students as partners (18.9\% definitely not and $6.6 \%$ rather not), they do not belong in the terminological meaning of Sustainable Development of the University. 


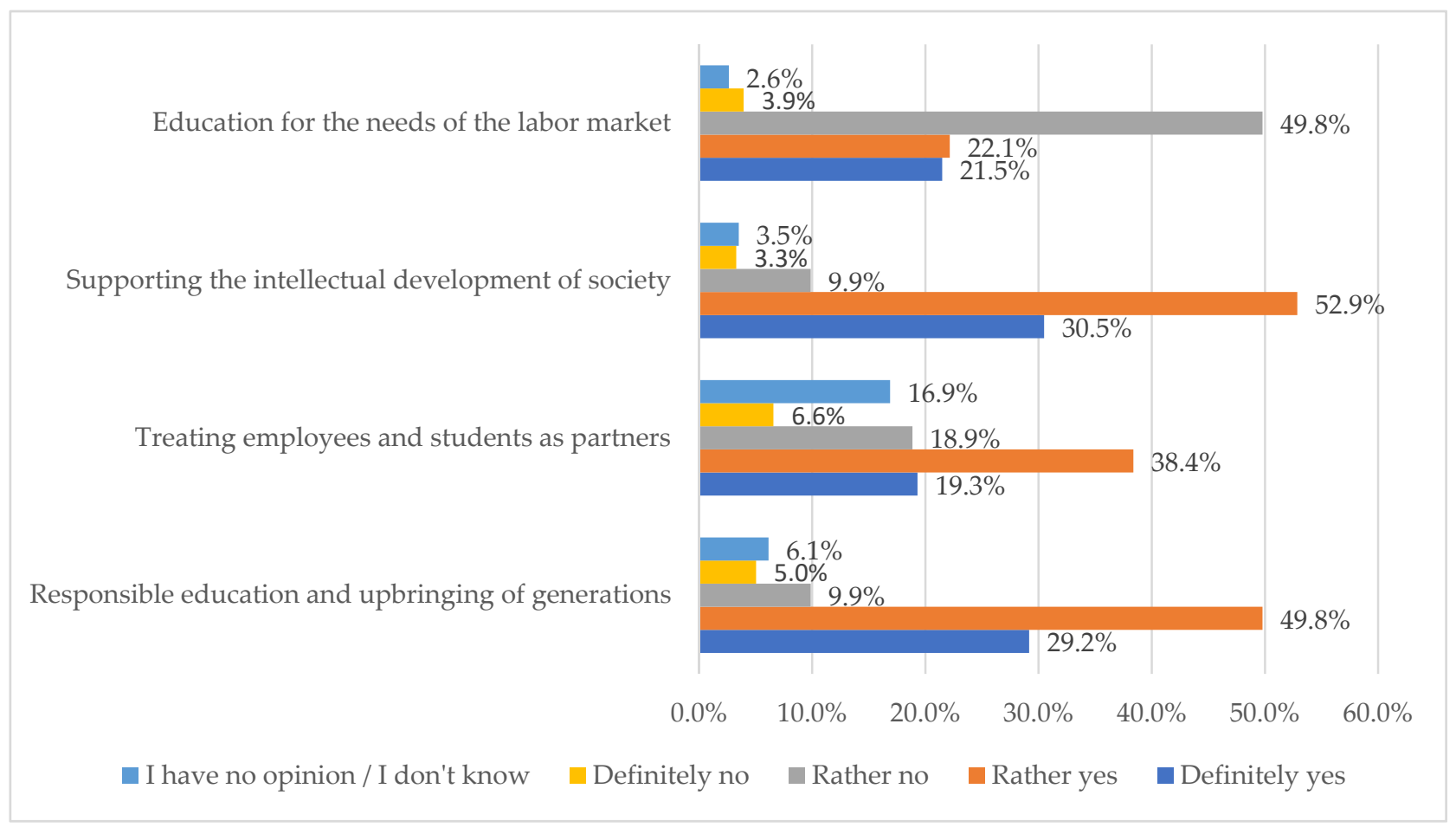

Figure 2. Meaning of the idea of 'Sustainable Development of the University'.

Such a result means that the Sustainable Development of the University is associated with utilitarian and missionary goals of education rather than operational and executive goals in relation to relations with the immediate environment and internal organizational ones.

According to the respondents representing public universities, the approach to sustainable development in the university's activities manifests itself in the following order: first, in building holistic study programs (47.9\% definitely yes and $30.6 \%$ rather yes), then in redefining the status of the universities, which are defined knowledge incubators and stimulators of innovative activities (46.5\% definitely yes and $31.3 \%$ rather yes), and third, in the creation of a new value system based on respect for diversity and elimination of social inequalities in terms of access to education (33.3\% definitely yes and $44.4 \%$ rather yes).

On the other hand, respondents from nonpublic universities claim that sustainable development in universities is manifested mainly in the creation of relational ecosystems. stimulators of innovative activities ( $42.0 \%$ definitely yes and $22.8 \%$ rather yes), and only in the third place in building holistic study programs (37.8\% definitely yes and 35.9\% rather yes).

The analysis of the respondents' statements regarding the impact of the idea of "Sustainable Development" on the way of thinking and acting at the university (Figure 3) indicates the existence of gradations of differentiation in the order of prioritization between public and nonpublic universities, which is indicated by the result of the analysis of the similarity of structures (Table 2) carried out using the Kolmogorov metric:

$$
d(p, q)=\frac{1}{2} \sum_{i=1}^{r}|p i-q i|
$$

This means that the key manifestations of the approach to sustainable development may result from the specification of activities in which the employees participate. Employees of public universities operating in Poland have been implementing the same curricula for many years, and the innovative approach and shaping values based on respect and elimination of social inequalities in terms of access to education have been inscribed in the university's DNA. Thus, the area perceived as significantly undergoing changes is 
precisely the study programs, and only then the other representations of changes follow. The opposite is true in the case of nonpublic universities, which flexibly adapted their study programs to the needs of the market. For the employees of these universities, a manifestation of significant changes are those resulting from greater emphasis on the creation of relational ecosystems of the university.
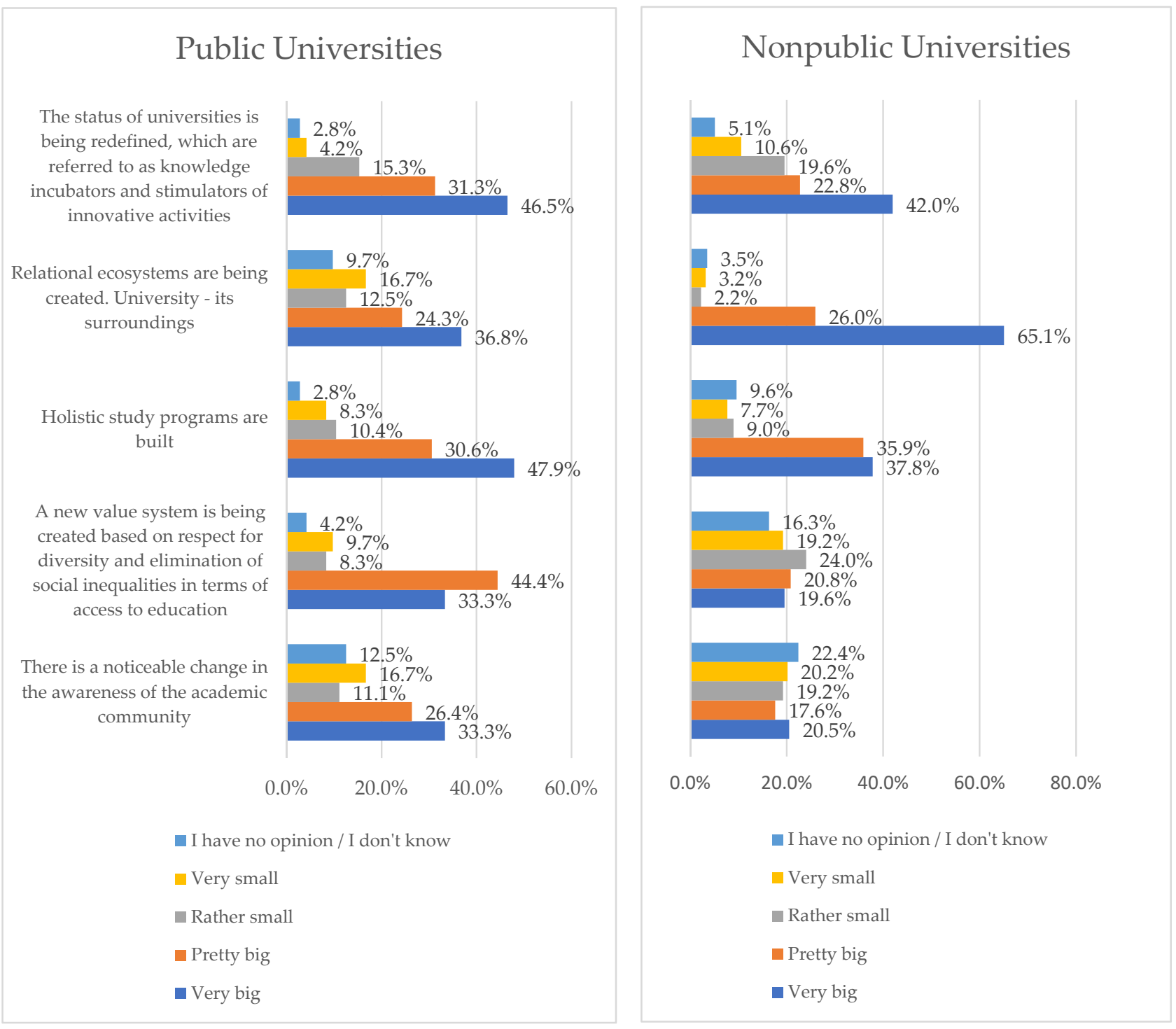

Figure 3. Influence of the idea of 'Sustainable Development' on the way of thinking and acting at the university.

Table 2. The similarity of the structure of the distribution of responses by respondents representing public and nonpublic universities regarding the impact of the idea of "Sustainable Development" on the way of thinking and acting at the university.

\begin{tabular}{cc}
\hline \multicolumn{1}{c}{ Similarity of Structures } & $d(p, q)$ \\
\hline there is a noticeable change in the awareness of the academic community & 0.215812 \\
\hline $\begin{array}{c}\text { a new value system is being created based on respect for diversity and } \\
\text { elimination of social inequalities in terms of access to education }\end{array}$ & 0.373932 \\
\hline holistic study programs are built & 0.121795 \\
\hline relational ecosystems university-its environment is being created. & 0.299145 \\
\hline $\begin{array}{l}\text { the status of universities is being redefined, which are referred to as } \\
\text { knowledge incubators and stimulators of innovative activities }\end{array}$ & 0.130342 \\
\hline
\end{tabular}


Worth analyzing are the results showing how the idea of Sustainable Development of the University determines the professionalization of activities in the field of university management (Table 3).

Table 3. The impact of the idea of "Sustainable Development" as a component of professionalization of activities in the field of university management (share in \%).

\begin{tabular}{|c|c|c|c|c|c|}
\hline Distribution of Answers in \% & Very Large & Quite Large & Rather Little & Very Little & $\begin{array}{l}\text { I Don't Know/I Don't } \\
\text { Have an Opinion }\end{array}$ \\
\hline \multicolumn{6}{|c|}{ Public universities } \\
\hline $\begin{array}{l}\text { will improve the position of the } \\
\text { university on the educational } \\
\text { market }\end{array}$ & 68.1 & 16.0 & 9.0 & 3.5 & 3.5 \\
\hline $\begin{array}{l}\text { will increase the university's } \\
\text { credibility by conducting more } \\
\text { projects with external } \\
\text { organizations }\end{array}$ & 36.8 & 31.9 & 19.4 & 9.0 & 2.8 \\
\hline $\begin{array}{l}\text { will strengthen the relationship } \\
\text { with the society }\end{array}$ & 31.3 & 29.9 & 23.6 & 11.8 & 3.5 \\
\hline $\begin{array}{l}\text { will allow the dissemination of } \\
\text { the ideas of equality, diversity, } \\
\text { tolerance, respect for human } \\
\text { rights and protection }\end{array}$ & 61.8 & 30.6 & 3.5 & 1.4 & 2.8 \\
\hline $\begin{array}{l}\text { will establish the principles of } \\
\text { mutual cooperation in the } \\
\text { workplace, cooperation between } \\
\text { departments and diversity } \\
\text { management in the workplace }\end{array}$ & 60.4 & 16.0 & 11.8 & 9.0 & 2.8 \\
\hline \multicolumn{6}{|c|}{ Nonpublic universities } \\
\hline $\begin{array}{l}\text { will improve the position of the } \\
\text { university on the educational } \\
\text { market }\end{array}$ & 61.2 & 28.5 & 6.7 & 2.6 & 1.0 \\
\hline $\begin{array}{l}\text { will increase the university's } \\
\text { credibility by conducting more } \\
\text { projects with external } \\
\text { organizations }\end{array}$ & 26.0 & 32.1 & 34.0 & 0.0 & 8.0 \\
\hline $\begin{array}{l}\text { will strengthen the relationship } \\
\text { with the society }\end{array}$ & 67.6 & 28.8 & 3.2 & 0.0 & 0.3 \\
\hline $\begin{array}{l}\text { will allow the dissemination of } \\
\text { the ideas of equality, diversity, } \\
\text { tolerance, respect for human } \\
\text { rights and protection }\end{array}$ & 57.4 & 35.3 & 2.2 & 3.2 & 1.9 \\
\hline $\begin{array}{l}\text { will establish the principles of } \\
\text { mutual cooperation in the } \\
\text { workplace, cooperation between } \\
\text { departments and diversity } \\
\text { management in the workplace }\end{array}$ & 47.1 & 48.7 & 0.3 & 1.0 & 2.9 \\
\hline $\begin{array}{l}\text { will improve the position of the } \\
\text { university on the educational } \\
\text { market }\end{array}$ & 61.2 & 28.5 & 6.7 & 2.6 & 1.0 \\
\hline
\end{tabular}

The university is an institution building principles and values, influencing the views of the society. Growing interest in sustainable development, care for social development and the quality of relations with the environment somehow set the university's natural direction of development. The respondents representing public universities indicate that the 
implementation of the idea of sustainable development as a component of professionalization of management is reflected in the improvement of the position of their universities on the educational market (68.1\% responses to a very large extent), allows the dissemination of the ideas of equality, diversity, tolerance, respect for human rights and protection $(61.8 \%$ responses to a very large extent) and strengthens the principles of mutual cooperation in the workplace, interdepartmental cooperation and diversity management in the workplace (60.4\% responses to a very large extent). On the other hand, the introduction of the idea of sustainable development will have little impact on increasing the credibility of their universities and strengthening relations with the society.

On the other hand, respondents belonging to the group of nonpublic universities believe that the idea of sustainable development as a component of professionalization of management will contribute to strengthening the relations of their universities with the society $(67.6 \%$ to a very large extent), will improve the position of the university on the educational market ( $61.2 \%$ to a very large extent) and will allow the dissemination of the idea of equality, diversity, tolerance, respect for human rights and protection (57.4\% to a very large extent). On the other hand, the introduction of the concept of sustainable development will not increase the credibility of their universities.

Such diversity in the approach to the importance of the idea of Sustainable Development as a component of the university's professionalization is confirmed by the results of comparing the structures (Table 4) with the Kolmogorov metric.

Table 4. The similarity of the structure of the distribution of responses by respondents representing public and private universities regarding the idea of "Sustainable Development" as a component of professionalization of activities in the field of university management.

\begin{tabular}{|c|c|}
\hline Similarity of Structures & $d(p, q)$ \\
\hline Will improve the position of the university on the educational market & 0.125534 \\
\hline $\begin{array}{l}\text { Will increase the university's credibility by conducting more projects with } \\
\text { external organizations }\end{array}$ & 0.198718 \\
\hline Will strengthen the relationship with the society & 0.363782 \\
\hline $\begin{array}{l}\text { Will allow the dissemination of the ideas of equality, diversity, tolerance, respect } \\
\text { for human rights and protection }\end{array}$ & 0.065171 \\
\hline $\begin{array}{l}\text { Will establish the principles of mutual cooperation in the workplace, cooperation } \\
\text { between departments and diversity management in the workplace }\end{array}$ & 0.328526 \\
\hline
\end{tabular}

\section{Summary}

The process of professionalization of management resulting from the growing requirement of competitiveness, technologization and social and economic transformations requires balancing the decisions made in line with the trend of social responsibility for the quality of services provided, maintaining transparency and system transparency, and in particular, respecting the idea of sustainable development. In this spirit, education, and especially universities, are treated as those institutions that should not only educate in the field of sustainable development, but above all implement the "environment-humaneconomy balance" themselves. In order to meet this demand, universities operating in Poland, both public and private, should operate in a transparent manner, and this is possible thanks to the comprehensive approach of management professionalization systems in terms of quality. Planning activities, organizing resources, implementing with information and controlling progress become the guarantor of the university's market position.

The analysis of the literature sources presented in the article as well as our own research clearly indicates trends and challenges in the implementation of the concept of sustainable development at universities. Universities understand the need for sustainable development in the context of their activities, and the professionalization of management at universities seems to be one of the priorities for the coming years. There is some difference 
in understanding and implementing the concept of sustainable development in public and private HEIs. For example, public universities identify sustainable development to a much lesser extent with the creation of an ecosystem of cooperation with stakeholders, which may result from their structure, organizational culture and sources of financing. On the other hand, nonpublic universities treat sustainable development to a lesser extent as the creation of a new value system based on diversity, elimination of social inequalities and open access to education. At the same time, public universities notice a change in the awareness of the existence of an integrated academic community to a greater extent. However, the differences between public and nonpublic HEIs in terms of understanding and implementing the concept of sustainable development and general professionalization of university management are not large. Representatives of both types of universities indicate that the main dimensions of the concept of sustainable development at universities are support for the broadly understood development of society and responsible education.

The literature on the subject referred to in this article as well as the practice of university management indicate the necessity of full involvement of the university in the process of promoting the concept of sustainable development. Analyzing the changes in the approach of higher education institutions to the concept of sustainable development, some basic discourses are indicated. The first discourse will give rise to the concept of environmental sustainability and care for the planet, while the second discourse is directed towards changes in the way the university is managed in a broad sense and changes in the ways of education.

\section{Conclusions}

In conclusion, it turns out that in accordance with the vision of third generation universities [80], the university can influence the process of creating a responsible society. Other authors [81-83] emphasize the crucial role of Higher Education Institutions in implementing practices for sustainable development in the education process, responding to the needs of stakeholders such as cooperation and dialogue between the academic community and the environment (enterprises, state and local government units). However, it requires both university managers and lecturers to focus on competences other than knowledge, namely shaping some kind of mentality and thinking about future generations. As the presented results show, employees of the universities participating in the survey are aware of the fact that they participate in creating a responsible society. Especially in the era of universal, global access to information, the role of the university will not be limited to creating knowledge but building and developing socially responsible attitudes. In this context, sustainable development is an important component of the professionalization of university management being an important decision-making component both in the strategic and operational dimensions $[84,85]$.

Figure 4 presents the process of creating a diversified quality culture in the direction of professionalization of management in the form of a working backwards scheme. The expected result, which is mature, diversified culture of management quality at a university, is backwardly decomposed under control of participants (shareholders in case of private universities and stakeholders in case of public universities) to implementation actions and idea. All areas must co-exist in the context of sustainable development of a university. 


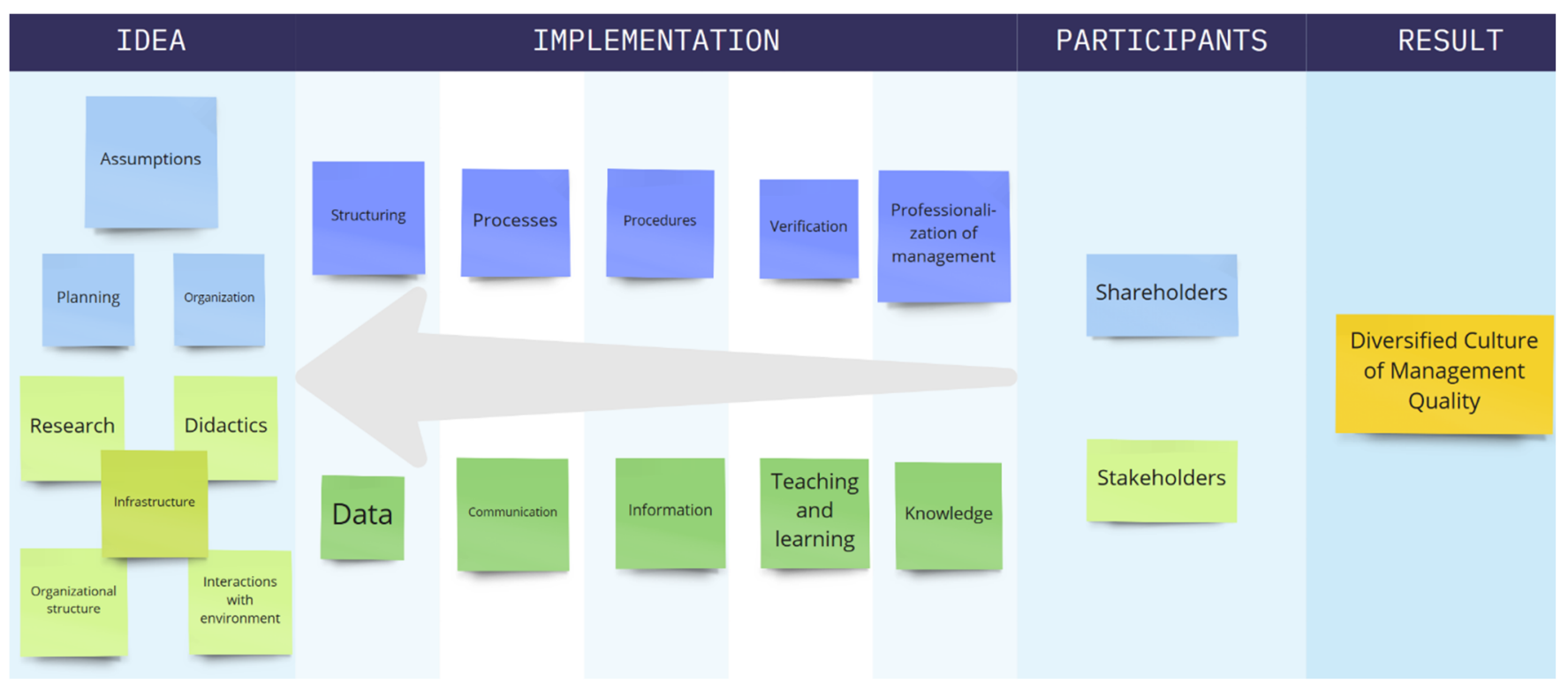

Figure 4. Creating a diversified quality culture in the direction of professionalization of management (created in miro.com "working backwards" tool based own research, accessed on 12 August 2021).

Such approach confirms the hypothesis that the idea of sustainable development implemented in the process of professionalization of university management supports the creation of a diverse quality culture. This is a huge challenge. Building sustainable universities requires transformation and reorganization. Extremely important here is the implementation of the idea of sustainable development in the organizational structure of the university and the fabric of the processes carried out. What really matters is open access to information, transparency of communication and emphasis on the involvement of members of the academic community. University employees should be informed and involved in the process of changes towards a mature and sustainable Higher Education Institution. An innovative approach requires sharing knowledge, promoting processes conducive to distribution and sharing of property, both in terms of research and teaching. Propagation of the idea of sustainable development should be represented both in a longterm strategic approach and in tactical and operational activities. The priority is to eliminate barriers and adapt ideas in both the scientific and functional fields. It is important to carry out research, exchange experiences between domestic and foreign educational centers as well as build study programs, prepare teachers and organize the educational process. Equally important is the operation of buildings, daily energy consumption, the use of machinery, equipment, means of transport and waste management [86,87].

Creating sustainable universities is a considerable challenge due to the current changes in the hierarchy of values and norms, standards, customs and broadly understood life priorities. The higher education 2.0 reform introduced in Poland forced university managers to redefine the vision and strategy of universities towards market integration, an immanent component of which is the concept of sustainable development. Creating sustainable universities is a long-term process due to the dichotomies appearing in the logic of the traditional approach of the academic institutions versus the business needs and requirements of the market. The transformations introduced are associated with a number of changes. The key is to introduce professionalization in management at universities, which means the necessity for organizations and their managers to acquire competences enabling effective management. It is particularly important to redefine the mission and strategy of the university towards marketization and changes in the management structure, emphasizing the role of managers and the university's accountability (indicators, rankings) due to initiatives taken in accordance with the idea of sustainable development. Only this approach through 
the implementation of the concept of sustainable development in the university's DNA can be considered a professionalization of management in higher education.

Finally, yes, universities are undergoing transformation in line with the idea of sustainable development. The backbone of changes is the introduced quality culture, which is a synthesis of academic culture and business methods of quality management in higher education, the signatories of which are vision and leadership, emphasizing the necessity of sustainable development. Consequently, the site managers are modernizing the infrastructure (e.g., lighting, heating) to be more environmentally friendly. They rebuild the organizational structure to take into account the participation of all stakeholders involved in the educational process. They implement various initiatives to raise awareness and promote the idea of sustainable development (environmental education programs) addressed to the general public and to the academic community.

University employees, both academics and administrative staff who participated in the study, are aware of the importance of implementing the concept of sustainable development both in the activities of the university as an organization and in the teaching process. Employees are aware of the changes. Employees of public universities associate them first with utilitarian and missionary goals and only secondly with operational and executive goals. On the other hand, for employees of nonpublic universities, first strategic and operational relationships in functional ecosystems are important, while research and teaching utilitarianism are treated with less importance.

In line with the idea of sustainable development, university managers made a number of decisions about infrastructure changes aimed at reducing energy consumption, reducing the level of waste generated and increasing the greening of campus areas. In turn, in planning study programs, the subject of sustainable development is more and more often taken into account, which is intended to contribute to a change in the perception of the availability and use of limited resources by students who will be decision makers in organizations in the future. Student exchange is also an important role in this area. The exchange of views, experiences and the acquisition of knowledge by participants of programs such as ERASMUS allows for confrontation of knowledge and gaining new experiences that can be used in the future. Learning to respect cultural diversity and gaining knowledge about innovative solutions can be a strong incentive to promote and implement the idea of sustainable development not only at universities, but also in the communities to which the participants of the exchange will return.

Teaching about sustainable development principles forces universities to act in accordance with their assumptions. Such approach may contribute to increasing the relationship of universities with their environment, which finally may result in the improvement of the image and position of the university on the educational market. In this area, activities may include programs disseminating the idea of equality, models of respect for diversity, supporting activities in the field of human rights and protection, strengthening the principles of cooperation with governmental and nongovernmental organizations involved in the implementation of the concept of sustainable development in the everyday functioning of societies.

The idea of sustainable development will live in the academic environment, outlining the trajectories of the future of the university on the basis of professionalization only if the respect for difference and diversity is respected. The involvement of the authorities plays a huge role. University authorities should not only postulate the idea of sustainable development in the context of strategic assumptions, but also take specific actions in the area of building structures, providing infrastructure and financial resources. People are the system and process binder. The culture of sustainable development of universities in the professionalization of management will guide the development of higher education in Poland. Utilitarianism and marketization may, in contrast, become symbiotic components of the new order of higher education.

Author Contributions: All authors have contributed to the conceptualization, while writing-review and editing was divided as follows: methodology, Ł.S. and P.B.; software, P.M.; validation, R.S. 
and P.M.; formal analysis, P.B. and R.S.; resources, K.K.-M. and P.M.; data curation, P.M.; writingoriginal draft preparation, Ł.S., P.B. and R.S.; writing-review and editing, Ł.S., K.K.-M., P.M. and R.S.; visualization, P.M.; supervision, K.K.-M.; project administration, K.K.-M. and R.S.; funding acquisition, Ł.S. and R.S. All authors have read and agreed to the published version of the manuscript.

Funding: This research was funded "Badania and profesjonalizacją zarządzania uczelniami w ramach projektu: "Dialog" (Decyzja Nr0146/DLG/2017/10)—w ramach obszaru badań nad “Wyzwaniami nowoczenej edukacji", statutowe środki Społeczna Akademia Nauk w Łodzi, Uniwersytet Ekonomiczny w Krakowie.

Institutional Review Board Statement: The study was conducted according to the guidelines of the Declaration of Helsinki, and approved by the Institutional Ethics Committee of University of Social Sciences (protocol code 2/2018 from 20 February 2018).

Informed Consent Statement: Informed consent was obtained from all subjects involved in the study.

Data Availability Statement: Not applicable.

Conflicts of Interest: The authors declare no conflict of interest.

\section{References}

1. Rieg, N.A.; Gatersleben, B.C.M.; Christie, I. Organizational Change Management for Sustainability in Higher Education Institutions: A Systematic Quantitative Literature Review. Sustainability 2021, 13, 7299. [CrossRef]

2. Ramírez-Montoya, M.S.; Andrade-Vargas, L.; Rivera-Rogel, D.; Portuguez-Castro, M. Trends for the Future of Education Programs for Professional Development. Sustainability 2021, 13, 7244. [CrossRef]

3. UNESCO. United Nations Educational, Scientific and Cultural Organization. United Nations' Decade of Education for Sustainable Development. 2005. Available online: https://en.unesco.org/themes/education-sustainable-development/what-is-esd/undecade-of-esd (accessed on 2 January 2021).

4. UNESCO, United Nations Educational, Scientific and Cultural Organization. The UN Decade of Education for Sustainable Development 2005-2014. The First Two Years. 2007. Available online: https://www.gcedclearinghouse.org/sites/default/ files/resources/\%5BENG\%5D\%20Los\%20dos\%20primeros $\% 20$ a $\%$ C3\%B1os $\% 20 \mathrm{del} \% 20 \mathrm{Decenio} \% 20 \mathrm{de} \% 201 \mathrm{as} \% 20 \mathrm{Naciones} \% 20$ Unidas\%20de\%20la\%20Educaci\%C3\%B3n\%20para\%20el\%20Desarrollo\%20Sostenible\%20\%282005-2014\%29.pdf (accessed on 2 January 2021).

5. Pilotti, M.A.E.; Al Ghazo, R. Sustainable Education Starts in the Classroom. Sustainability 2020, 12, 9573. [CrossRef]

6. UNESCO, United Nations Educational, Scientific and Cultural Organization. Teaching and Learning for Sustainable Future. 2010. Available online: http://www.unesco.org/science/doc/cc/plenaryII/TLSF_ClaytonWhite.pdf (accessed on 12 May 2021).

7. UNESCO, United Nations Educational, Scientific and Cultural Organization. Education for Sustainable Development Lens: A Policy and Practice Review Tool. 2010. Available online: https://www.educationcbd.org/Tools_Decision/021020151201292.pdf (accessed on 12 May 2021).

8. Costes, N.; Hopbach, A.; Kekäläinen, H.; Ijperen, R.V.; Walsh, P. Quality Assurance and Transparency Tools. European Association for Quality Assurance in Higher Education; European Association for Quality Assurance in Higher Education: Helsinki, Finland, 2010.

9. Normand, R. (Ed.) The politics of standards and quality. In The Changing Epidemic Governance of European Education; Educational Governance Research 3; Springer: New York, NY, USA, 2016; pp. 63-94.

10. Banta, T.W.; Palomba, C.A. Assessment Essentials: Planning, Implementing, and Improving Assessment in Higher Education; Jossey-Bass: San Francisco, CA, USA, 2015.

11. Harvey, L.; Newton, J. Transforming quality evaluation: Moving on. In Quality Assurance in Higher Education: Trends in Regulation, Translation, and Transformation; Westerheiden, D.D., Stensaker, B., Rosa, M.J., Eds.; Springer: Dordrecht, The Netherlands, 2007; pp. 225-246.

12. Martensson, K.; Roxa, T.; Olsson, T. Developing a quality culture through the Scholarship of Teaching and Learning. High. Educ. Res. Dev. 2011, 30, 51-62. [CrossRef]

13. Smidt, H. European quality assurance: A European higher education area success story. In The European Higher Education Area: Between Critical Reflections and Future Policies: Part II; Curaj, A., Matei, L., Pricopie, R., Salmi, J., Scott, P., Eds.; Springer: Cham, Switzerland, 2015; pp. 625-637.

14. EUA. Developing an Internal Quality Culture in European Universities Report on the Quality Culture Project; EUA: Brussels, Belgium, 2005.

15. Yu, M.C.; Mai, Q.; Tsai, S.B.; Dai, Y. An empirical study on the organizational trust, employee-organization relationship and innovative behavior from the integrated perspective of social exchange and organizational sustainability. Sustainability 2018, 10, 864. [CrossRef]

16. Kottmann, A.; Huisman, J.; Brockerhoff, L.; Cremonini, L.; Mampaey, J. How Can One Create a Culture for Quality Enhancement; Final Report; Ghent University: Ghent, Belgium, 2016.

17. Craft, A. International Developments in Assuring Quality in Higher Education; Routledge: London, UK, 2018. 
18. Seyfried, M.; Ansmann, M. Unfreezing higher education institutions? Understanding the introduction of quality management in teaching and learning in Germany. High. Educ. 2018, 75, 1061-1076. [CrossRef]

19. Geven, K.; Maricut, A. A merry-go-around of evaluations moving from administrative burden to reflection on education and research in Romania. In The European Higher Education Area: Between Critical Reflections and Future Policies: Part II; Curaj, A., Matei, L., Pricopie, R., Salmi, J., Scott, P., Eds.; Springer: Cham, Switzerland, 2015; pp. 665-684.

20. Sułkowski, L.; Seliga, R.; Wozniak, A. Kultura organizacyjna i zarządzanie uczelnią z punktu widzenia systemu zapewniania jakości w Polsce. Przedsiębiorczość Zarządzanie 2016, 17, 221-233.

21. Sułkowski, L.; Seliga, R.; Wozniak, A. Rezultaty badań kultur jakości uczelni wyższych w Polsce. Przedsiębiorczość Zarządzanie 2016, 17, 75-90.

22. Sułkowski, L.; Seliga, R.; Wozniak, A. Quality Culture in Polish Higher Education Institutions-Multi-Paradigmatic Perspective. In Management and Culture of the University; Sulkowski, L., Ed.; Peter Lang: Bern, Switzerland, 2017; pp. 9-77.

23. Vlăsceanu, L.; Grünberg, L.; Pârlea, D. Quality Assurance and Accreditation: A Glossary of Basic Terms and Definitions; Unesco-Cepes: Bucharest, Romania, 2007; pp. 33-40.

24. Van Weenen, H. Towards a vision of a sustainable university. J. Sustain. High. Educ. 2000, 1, 20-34. [CrossRef]

25. Eccles, R.G.; Perkins, K.M.; Serafeim, G. How to Become a Sustainable Company. MIT Sloan Manag. Rev. 2012, 53, 43-50.

26. Gaston, P.L. Higher Education Accreditation: How It's Changing, Why It Must; Stylus Publishing: Sterling, VA, USA, 2014.

27. Hugé, J.; Waas, T.; Dahdouh-Guebas, F.; Koedam, N.; Block, T. A discourse-analytical perspective on sustainability assessment: Interpreting sustainable development in practice. Sustain. Sci. 2013, 8, 187-198. [CrossRef]

28. Waas, T.; Hugé, J.; Verbruggen, A.; Wright, T. Sustainable Development: A Bird's Eye View. Sustainability 2011, 3, 1637-1661. [CrossRef]

29. Nielsen, K.A.; Elling, B.; Figueroa, M.; Jelsoe, E. A New Agenda for Sustainability; Ashgate Publishing Ltd.: Farnham, UK, 2010.

30. Rametsteiner, E.; Puelzl, H.; Alkan-Olsson, J.; Frederiksen, P. Sustainability indicator development: Science or political negotiation? Ecol. Indic. 2011, 11, 61-70. [CrossRef]

31. Brehmer, M.; Podoynitsyna, K.; Langerak, F. Sustainable business models as boundary-spanning systems of value transfers. J. Clean. Prod. 2018, 172, 4514-4531. [CrossRef]

32. Geissdoerfer, M.; Vladimirova, D.; Evans, S. Sustainable business model innovation: A review. J. Clean. Prod. 2018, 198, 401-416. [CrossRef]

33. Hoover, E.; Harder, M. What Lies Beneath the Surface? The Hidden Complexities of Organizational Change for Sustainability in Higher Education. J. Clean. Prod. 2014, 106. [CrossRef]

34. Lozano, R.; Lukman, R.; Lozano, F.J.; Huisingh, D.; Lambrechts, W. Declarations for sustainability in higher education: Becoming better leaders, through addressing the university system. J. Clean. Prod. 2013, 48, 10-19. [CrossRef]

35. Wals, A.E.J. Sustainability in higher education in the context of the un DESD: A review of learning and institutionalization processes. J. Clean. Prod. 2014, 62, 8-15. [CrossRef]

36. Moore, J. Barriers and pathways to creating sustainability education programs: Policy, rhetoric and reality. Environ. Educ. Res. 2005, 11, 537-555. [CrossRef]

37. Dzimińska, M.; Fijalkowska, J.; Sulkowski, L. Trust-Based Quality Culture Conceptual Model for Higher Education Institutions. Sustainability 2018, 10, 2599. [CrossRef]

38. Bendermacher, G.W.G.; oude Egbrink, M.G.A.; Wolfhagen, I.H.A.P.; Dolmans, D.H.J.M. Unravelling quality culture in higher education: A realist review. High. Educ. 2017, 73, 39-60. [CrossRef]

39. Harvey, L.; Stensaker, B. Quality culture: Understandings, boundaries and linkages. Eur. J. Educ. 2008, 43, 427-442. [CrossRef]

40. Tilbury, D.; Keogh, A.; Leighton, A.; Kent, J. A National Review of Environmental Education and Its Contribution to Sustainability in Australia: Further and Higher Education; Australian Government Department of the Environment and Heritage and Australian Research Institute in Education for Sustainability: Canberra, Australia, 2005.

41. Ferrer-Balas, D.; Adachi, J.; Banas, S.; Davidson, C.I.; Hoshikoshi, A.; Mishra, A.; Motodoa, Y.; Onga, M.; Ostwald, M. An international comparative analysis of sustainability transformation across seven universities. Int. J. Sustain. High. Educ. 2008, 9, 295-316. [CrossRef]

42. Pinto, J. A multifocal framework for developing Intentionally Sustainable Organizations. Curr. Opin. Environ. Sustain. 2017, 28, 17-23. [CrossRef]

43. Nidumolu, R.; Prahalad, C.; Rangaswami, M. Why sustainability is now the key driver of innovation. Harv. Bus. Rev. 2009, $87,56-64$.

44. Schaltegger, S.; Freund, F.L.; Hansen, E.G. Business cases for sustainability: The role of business model innovation for corporate sustainability. Int. J. Innov. Sustain. Dev. 2012, 6, 95. [CrossRef]

45. Wals, A.; Blewitt, J. Third-wave sustainability in higher education: Some (inter)national trends and developments. In Sustainability Education; Jones, P., Selby, D., Sterling, S., Eds.; Earthscan: London, UK, 2010; pp. 55-74.

46. Lozano, R. The state of sustainability reporting in universities. Int. J. Sustain. High. Educ. 2011, 12, 67-78. [CrossRef]

47. Lozano, R.; Lozano, F.J.; Mulder, K.; Huisingh, D.; Waas, T. Advancing Higher Education for Sustainable Development: International insights and critical reflections. J. Clean. Prod. 2013, 48, 3-9. [CrossRef]

48. Grace, A.; Rocco, T. Challenging the Professionalization of Adult Education; Wiley and Sons: San Francisco, CA, USA, 2009. 
49. Collazo Expósito, L.M.; Granados Sánchez, J. Implementation of SDGs in University Teaching: A Course for Professional Development of Teachers in Education for Sustainability for a Transformative Action. Sustainability 2020, 12, 8267. [CrossRef]

50. Sułkowski, Ł.; Bednarek, M.; Parkes, A. Kulturowa Zmienność Procesów Zarzadzania; Difin: Warszawa, Poland, 2016.

51. Howorth, C.; Wright, M.; Westhead, P.; Allcock, D. Company metamorphosis: Professionalization waves, family firms and management buyouts. Small Bus. Econ. 2016, 47, 803-817. [CrossRef]

52. Fanning, B. Human Resource Management: The Road to Professionalization in the UK and USA. Master's Thesis, Kingston University, Kingston upon Thames, UK, 2011.

53. Hoyle, E. Professionalization and deprofessionalization in education. In World Yearbook of Education 1980: The Professional Development of Teachers; Hoyle, E., Megarry, J., Eds.; Routledge: London, UK, 2012.

54. Dekker, J.; Lybaert, N.; Steijvers, T.; Depaire, B. The effect of family business professionalization as a multidimensional construct on firm performance. J. Small Bus. Manag. 2015, 53, 516-538. [CrossRef]

55. Boitier, M.; Rivière, A. Changing professions? The professionalization of management in universities. In Multi-Level Governance in Universities; Springer: Cham, Switzerland, 2016; pp. 95-113.

56. Boitier, M.; Rivière, A. Freedom and responsibility for French universities: From global steering to local management. Account. Audit. Account. J. 2013, 26, 616-649. [CrossRef]

57. Powell, W.; Colyvas, J. Microfoundations of institutional theory. In Handbook of Organizational Institutionalism; Greenwood, R., Oliver, C., Sahlin, K., Suddaby, R., Eds.; Sage: London, UK, 2008.

58. Dubar, C.; Tripier, P.; Boussard, V. Sociologie des Professions; Armand Colin: Paris, France, 2011.

59. Collini, S. What Are Universities for? Penguin Books: London, UK, 2012.

60. Aravena-Gaete, M.; Campos-Soto, M.N.; Rodríguez-Jiménez, C. Learning Strategies at a Higher Taxonomic Level in Primary Education Students in the Digital Age. Sustainability 2020, 12, 9877. [CrossRef]

61. Newman, J. An Organizational Change Management Framework for Sustainability. Greener Manag. Int. 2012, 57, 65-75.

62. Mazhar, M.U.; Bull, R.; Lemon, M.; Mallaburn, P. The current state of strategic carbon management within the UK higher education sector: Leading the way forward? In Proceedings of the 9th International Symposium on Sustainable Leadership, Salzburg, Austria, 3-6 June 2014; pp. 148-160.

63. Wright, T.; Horst, N. Exploring the ambiguity: What faculty leaders really think of sustainability in higher education. Int. J. Sustain. High. Educ. 2013, 14, 209-227. [CrossRef]

64. Verhulst, E.; Boks, C. The role of human factors in the adoption of sustainable design criteria in business: Evidence from Belgian and Dutch case studies. Int. J. Innov. Sustain. Dev. 2012, 6, 146-163. [CrossRef]

65. Sylvestre, P.; Wright, T.; Sherren, K. Exploring Faculty Conceptualizations of Sustainability in Higher Education: Cultural Barriers to Organizational Change and Potential Solutions. J. Educ. Sustain. Dev. 2013, 7, 223-244. [CrossRef]

66. Oketch, M. Financing higher education in sub-Saharan Africa: Some reflections and implications for sustainable development. High. Educ. 2016, 72, 525-539. [CrossRef]

67. Levy, D.C. The decline of private higher education. High. Educ. Policy 2013, 26, 25-42. [CrossRef]

68. Yang, L.; McCall, B. World education finance policies and higher education access: A statistical analysis of World Development Indicators for 86 countries. Int. J. Educ. Dev. 2014, 35, 25-36. [CrossRef]

69. Kinser, K.; Levy, D.C.; Casillas, J.C.S.; Bernasconi, A.; Slantcheva-Durst, S.; Otieno, W. The Global Growth of Private Higher Education; ASHE Higher Education Report; Wiley: Hoboken, NJ, USA, 2010; p. 36.

70. Owens, T.L. Higher education in the sustainable development goals framework. Eur. J. Educ. 2017, 52, 414-420. [CrossRef]

71. Wu, Y.-C.J.; Shen, J.P. Higher education for sustainable development: A systematic review. Int. J. Sustain. High. Educ. 2016, 17, 633-651. [CrossRef]

72. Cortese, A. The critical role of higher education in creating a sustainable future. Plan. High. Educ. 2003, 31, 15-22.

73. Orr, D.W. Four challenges of sustainability. Conserv. Biol. 2002, 16, 1457-1460.

74. Barlett, P.; Chase, G. Sustainability on Campus: Stories and Strategies for Change; MIT Press: Cambridge, MA, USA, 2004.

75. Rowe, D. Education for a sustainable future. Science 2007, 31, 323-324. [CrossRef]

76. Concannon, F.; Flynn, A.; Campbell, M. What campus-based students think about the quality and benefits of e-learning. Br. J. Educ. Technol. 2005, 36, 501-512. [CrossRef]

77. Senge, P.M.; Smith, B.; Kruschwitz, N.; Laur, J.; Schley, S. The Necessary Revolution. How Individuals and Organizations Are Working Together to Create a Sustainable World; Doubleday: New York, NY, USA, 2008.

78. Bañegil-Palacios, T.M.; Sánchez-Hernández, M.I. The challenge to foster foreign students' experiences for sustainable higher educational institutions. Sustainability 2018, 10, 495. [CrossRef]

79. Salihu, M.J.; Ramadneh, N.M.; Rashid, R.A.A. Sustainable higher education leadership: A conceptual approach from the functionalist paradigm for higher institutions of learning. Humanit. Soc. Sci. Rev. 2020, 8. [CrossRef]

80. Wissema, J.G. Uniwersytet Trzeciej Generacji. Uczelnia XXI Wieku; Zante: Zębice, Poland, 2009.

81. Caeiro, S.; Sandoval Hamón, L.A.; Martins, R.; Bayas Aldaz, C.E. Sustainability Assessment and Benchmarking in Higher Education Institutions-A Critical Reflection. Sustainability 2020, 12, 543. [CrossRef]

82. Farinha, C.; Caeiro, S.; Azeiteiro, U. Sustainability Strategies in Portuguese Higher Education Institutions: Commitments and Practices from Internal Insights. Sustainability 2019, 11, 3227. [CrossRef] 
83. Pompeii, B.; Chiu, Y.-W.; Neill, D.; Braun, D.; Fiegel, G.; Oulton, R.; Ragsdale, J.; Singh, K. Identifying and Overcoming Barriers to Integrating Sustainability across the Curriculum at a Teaching-Oriented University. Sustainability 2019, 11, 2652. [CrossRef]

84. Woods, J.A. The Six Values of a Quality Culture; CWL Publishing Enterprises: Madison, WI, USA, 1998.

85. Sachs, J.D.; Kroll, C.; Lafortune, G.; Fuller, G.; Woelm, F. Sustainable Development Report; Cambridge University Press: Cambridge, UK, 2021.

86. Jill Yielder, J.; Codling, A. Management and Leadership in the Contemporary University. J. High. Educ. Policy Manag. 2004, 26, 315-328. [CrossRef]

87. Söderhjelm, T.; Björklund, C.; Sandahl, C.; Bolander-Laksov, K. Academic leadership: Management of groups or leadership of teams? A multiple-case study on designing and implementing a team-based development programme for academic leadership. Stud. High. Educ. 2018, 43, 201-216. [CrossRef] 